\title{
Analisis Model Pengelolaan Zakat, Infaq dan Shadaqah (ZIS) di Mesjid Al Istiqomah Kabupaten Bandung Barat
}

\author{
Amrullah Hayatudin ${ }^{1 *}$, Arif Rijal Anshori ${ }^{2)}$ \\ ${ }^{1,2}$ Fakultas Syariah Universitas Islam Bandung \\ *Email korespondensi: amrullahhayatudin@unisba.ac.id
}

This research was conducted as an effort to find the right model in the management of Zakat, Infaq, and Sadaqah (ZIS) at the Al Istiqomah Mosque, Taman Bunga Cilame districts of West Bandung. With the hope of an appropriate model in the management of Zakat, Infaq, and Shadaqah (ZIS) funds. The purpose of Zakat, Infaq, and Shadaqah (ZIS) as a means of worship and social means, namely as a means to alleviate poverty and prosper the people can be achieved. The method used by researchers is qualitative, the data collection technique is observation (observation), interview (interview), and documentation, in analyzing the data the researcher uses qualitative data analysis is inductive. In managing ZIS funds, three things must be considered by DKM administrators, namely: Excellent service for muzakki and mustahik, funds (ZIS) must be utilized properly, transparently, creatively, and innovatively. With the management model as follows: Providing additional capital to mustahik by using aqad Mudharabah or Musyarakah; Assistance with the Participatory Action Research (PAR) approach to mustahik.

Keywords : Zakat, Infaq Shadaqah

Saran sitasi: Hayatudin, A., \& Anshori, A. R. (2021). Analisis Model Pengelolaan Zakat, Infaq dan Shadaqah (ZIS) di Mesjid Al Istiqomah Kabupaten Bandung Barat. Jurnal Ilmiah Ekonomi Islam, 7(02), 661-668. doi:http://dx.doi.org/10.29040/jiei.v7i2.2230

DOI: http://dx.doi.org/10.29040/jiei.v7i2.2230

\section{PENDAHULUAN}

Zakat adalah salah satu rukun Islam yang memiliki komitmen sosial yang begitu jelas, bahkan merupakan ibadah yang sangat penting, untuk menumbuhkan jiwa sosial pelakunya karena Zakat menyentuh hajat orang banyak yaitu sebagai pemenuhan kebutuhan ekonomi masyarakat yang membutuhkan (mustahiq) (Masudi, 1993).

Zakat dalam Islam mempunyai peranan sangat penting dan strategis sebagai media dalam upaya pengentasan kemisikan dan juga pembangunan ekonomi umat. Zakat tidak memiliki dampak baik apapun kecuali keridhaan pemberi Zakat, dan harapan zakatnya diberi ganjaran Pahala oleh Allah Swt. Namun demikian, bukan berarti mekanisme zakat tidak ada kontrolnya (Nizar, 2016).

Menurut Ali Hasan (2006) Nilai strategis zakat dapat terlihat dari: Pertama, Zakat merupakan Kewajiban dari Allah Swt. Sebagai cerminan keimanan bagi pelakunua. Kedua, sumber keuangan zakat akan selalu ada sepanjang Agama Islam masih ada. Artinya (muzakki), tidak akan pernah habis dan setiap tahunnya mereka akan selalu membayar Zakat. Ketiga, zakat secara empirik dapat menghilangkan kesenjangan sosial antara si papa dan si kaya, bahkan zakat dapat menciptakan redistribusi aset dan pemerataan pembangunan.

Namun, zakat bukanlah satu-satunya intitusi dalam hukum Islam yang bisa digunakan untuk kesejahteraan umat. Masih ada Infaq dan sodaqoh yang bisa digunakan. Oleh karena itu, tidak hanya institusi zakat saja yang harus didorong untuk dapat menciptakan lapangan usaha produktif bagi kelompok masyarakat yang tidak mampu, yang termasuk dalam kelompok yang berhak menerima zakat, tetapi Infaq dan Sedekah juga perlu dikelola dengan baik.

Agar dana Zakat, Infaq dan Sodaqoh bisa menjadi sumber yang bermanfaat untuk meningkatkan kesejahteraan umat, terutama untuk mengentaskan kemiskinan dan kesenjangan sosial, maka perlu 


\section{Jurnal Ilmiah Ekonomi Islam, 7(02), 2021, 662}

adanya pengelolaan yang baik terkait tiga dana tersebut (A. Hasan, 2006).

Di Indonesia, pengelolaan zakat diatur berdasarkan Undang-Undang Nomor 38 Tahun 1999 tentang Pengelolaan Zakat dengan Keputusan Menteri Agama (KMA) Nomor 581 Tahun 1999 tentang Pelaksanaan Undang-Undang Nomor 38 Tahun 1999 dan Keputusan Direktur Jenderal Bimbingan Masyarakat Islam dan Urusan Haji No. D/291 tentang Pedoman Teknis Pengelolaan Zakat (Nizar, 2016). Meskipun faktanya pengelolaan Zakat di Indonesia masih sangat kurang maksimal. Hal ini terlihat dari data 2020-2016 kemiskinan di Indonesia masih tinggi, meskipun cenderung menurun (Dwihapsari, 2017).

Padahal sebenarnya islam sudah menawarkan konsep pemberdayaan ekonomi umat, yang bisa membebaskan umat dari jaring-jaring ekonomi kapitalis. Banyak sarana yang ditawarkan Islam dan jika dengan system pengelolaan yang baik, sarana tersebut mampu meminimalisir kesenjangan ekonomi umat, yaitu dengan memaksimalkan peran-peran, zakat, infaq Sodaqoh, dengan merevitalisasi peran lembaga ekonomi makro seperti baitul mal wat tamwi (Basid, 2009).

Untuk menjawab problem umat yang eskalasinya semakin meningkat, terutama terkait dengan semakin tingginya kesenjangan sosial dan tingkat kemiskinan umat Islam, maka umat Islam perlu kembali ke Masjid. Masjid merupakan salah satu Lembaga keagamaan, tempat perjumpaan dan berkumpulnya umat Islam secara rutin. Perkumpulan tersebut dilandasi dengan hati dan pikiran yang jernih, yang tentu sangat berbeda dengan tempat-tempat perkumupulan yang lain. Hal ini dikarenakan masjid merupakan tempat suci umat islam, tempat dimana mereka mendekatkan diri kepada Allah Swt, maka, umat Islam yang mendatanginya merupakan Umat yang berniat untuk bermunajat mendekatkan diri kepada Allah Swt. Namun, Pada satu sisi masjid juga merupakan ruang publik untuk bersama-sama membahas berbagai persoalan keumatan yang ada di lingkungannya. Oleh karena itu, jamaah masjid adalah basis-basis komunitas yang sangat kokoh. (Suryanto \& Saepulloh, 2016)

Dalam menghadapi problema yang dihadapi umat Islam dewasa ini, terutama terkait dengan Ekonomi umat, masjid dapat dijadikan sentral kekuatan umat. Sebagaimana yang sudah dilakukan pada masa lalu, pada masa Nabi, masjid dapat diperankan secara maksimal sebagai sentral umat
Islam untuk berbagai kegiatan, seperti ibadah, pendidikan, militer, sosial dan ekonomi (Basid, 2009).

Salah satu, masjid yang dijadikan objek penelitian terkait dengan pengelolaan dana ZIS adalah Mesjid Al Istiqomah Komplek Taman Bunga Cilame, yang berlokasi di Desa Cilame Kecamatan Ngamprah Kabutapen Bandung Barat. Peneliti menjadikan Mesjid Al Istiqomah sebagai lokasi penelitian, karena menurut hasil wawancara dengan Pengurus DKM masjid tersebut, belum mempunyai model pengelolaan Dana ZIS yang transfaran dan akuntabel.

Hal tersebut yang melatarbelakangi ketertarikan peneliti untuk melakukan penelitian sekaligus pelatihan terkait dengan model pengelolaan dana ZIS di Mesjid tersebut. Penelitian ini mengkaji tentang model yang tepat yang bisa digunakan masjid dalam mengelola dana titipan Umat, dalam bentuk zakat, infaq dan shadaqoh. Analisa ini bermanfaat untuk menjembatani kesenjangan antara tingginya Dana ZIS yang diterima, dengan rendahnya pengetahuan pengurus DKM terkait dengan model pengelolaan dana tersebut. Dengan adanya model pengelolaan yang baik dan tepat, diharapkan dana ZIS dapat bermanfaat untuk kesejahteraan masyarakat di lingkungan Mesjid tersebut.

Penelitian ini menggunakan metode kualitatif, dengan fokus yang diarahkan pada realitas sosial yang berubah dan sebagai hasil konstruksi sosial yang berlangsung antara pelaku dan institusi sosial. Penelitian kualitatif ini mengangkat sebuah fenomena yang terjadi dalam ruang lingkup masjid. Penelitian kualitatif merupakan penelitian yang menggunakan pendekatan naturalistik untuk menemukan pemahaman mengenai fenomena dalam suatu latar yang berkonteks khusus. Penelitian kualitatif adalah penelitian yang terjadi pada lingkup sosial yang mencakup pelaku, kejadian, tempat, dan waktu. Keempat cakupan tersebut dinamakan social setting (Moleung, 2005).

\section{METODE PENELITIAN}

\subsection{Jenis Penelitian}

Penelitian ini merupkan penelitian kualitatif, yang disajikan dalam bentuk deskriftif Penelitian ini bersifat Kualitatif. Menurut Bogdan dan Taylor didalam buku Lexy J. Maleong, Metodologi Penelitian Kualitatif Edisi Revisi mendifinisikan metodologi kualitatif sebagai prosedur penelitian yang menghasilkan data deskriptif berupa kata-kata atau 


\section{Jurnal Ilmiah Ekonomi Islam, 7(02), 2021, 663}

lisan dari orang-orang dan perilaku yang diamati (Maleong, 2014).

\subsection{Lokasi Penelitian}

Penelitian terkait Analisis Model Pengelolaan Zakat, Infaq Dan Shadaqah (ZIS) ini dilakukan di Mesjid Al Istiqomah Komplek Taman Bunga Cilame, Desa. Cilame Kecamatan Ngamprah kabupaten. Bandung Barat, Jawa Barat.

\subsection{Teknik Pengumpulan dan Analisis Data}

Peneliti memperoleh data penelitian dari hasil observasi (pengamatan), interview (wawancara), dan dokumentasi, dengan sumber primer (jurnal, buku, tesis, disertasi, melakukan wawancara dengan Ketua DKM, Pengurus DKM dan Jamaah Mesjid), sedangkan data sekunder didapat dari (literaturlitearur yang relevan dengan masalah penelitian). Data-data tersebut kemudian dianalisis dengan menggunakan teknik pengolahan data kualitatif. Yang dimaksud dengan teknik pengolahan data kualitatif ialah, peneliti memilih data dengan kualitasnya untuk dapat menjawab permasalahan yang diajukan. Untuk penyajiannya dilakukan secara deskriptif analisis yaitu suatu cara analisa data yang dilakukan dengan jalan menyusun secara sistematis sehingga diperoleh kesimpulan yang ilmiah yang merupakan jawaban dari permasalahan yang diajukan.

\section{HASIL DAN PEMBAHASAN}

\subsection{Definisi dan Peran Mesjid}

Secara etimologi kata Masjid bahasa berasal dari

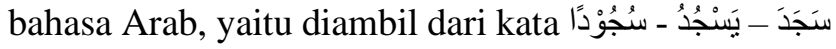

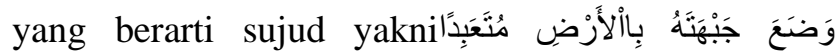
(meletakan dahi ke bumi untuk beribadah) (Munawir, 1984).

Sesungguhnya untuk sujud atau mengerjakan shalat, boleh dilakukan di mana saja asal tidak ada larangan, sebagaimana dinyatakan sabda Nabi SAW:

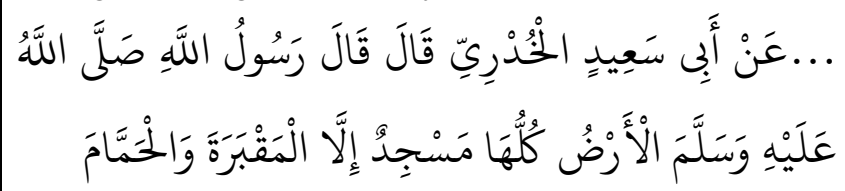

"... Dari Abu Sa'id Al Khudri ia berkata;

"Rasulullah Saw bersabda: "Bumi ini seluruhnya adalah masjid kecuali kuburan dan kamar mandi." (HR. Muslim)

Hadits tersebut di atas tersebut memberikan suatu pemahaman, bahwa tempat untuk bersujud atau mengerjakan shalat tidak terikat pada tempat tertentu, akan tetapi boleh dilakukan di mana saja di alam semesta ini bahkan boleh dilakukan di kandang ternak sekalipun, asal memenuhi ketentuan-ketentuan yang telah ditetapkan (Aziz Muslim, 2005).

Sementara secara istilah definisi masjid terdapat beberapa definisi yang disampaikan para ulama diantaranya yang disampaikan oleh An-Nasafi, beliau berpendapat bahwa masjid adalah "Rumah yang dibangun khusus untuk shalat dan beribadah di dalamnya kepada Allah."(Nasafi, t.t). Definisi yang hampir sama disampaikan oleh Al-Qadhi Iyadh, menurutnya masjid merupakan tempat di muka bumi yang memungkinkan untuk menyembah dan bersujud kepada Allah. (Al-Qurthubi, 2006)

Jadi, masjid dalam arti khusus merupakan suatu bangunan suci bagi umat islam, yang fungsi utamanya sebagai tempat untuk mendekatkan diri kepada Allah Swt (Ibadah Mahdhah). Namun, di samping sebagai tempat melaksanakan (Ibadah Mahdhah), masjid juga bisa menjadi salah satu tempat beribadah (Ghairu Mahdhah), tentu dengan ketentuan-ketantuan Syariah Islam (Siskandar, 2020).

Menurut Gazalba (1971) Masjid tidak hanya bisa digunakan untuk shalat saja, tetapi masjid bisa digunakan sebagai sekolahan, balai pertemuan dan tempat untuk mempertemukan dan mempersatukan semua unsur masyarakat Islam. Bahkan Mesjid bisa juga digunakan juga tempat untuk mengatur berbagai urusan, bermusyawarah dan menjalankan roda pemerintahan. Masjid yang besar, bersih, dan indah merupakan dambaan, namun hal tersebut tidaklah cukup jika tanpa ditunjang dengan aktivitas untuk memakmurkan masjid.

Berdasarkan uraian di atas dapat dipahami bahwa masjid merupakan tempat ibadah yang multifungsi. Yang mana bukan hanya temoat untuk shalat tetapi bisa dijadikan tempat kegiatan-kegiatan positif lainnya, yang kiranya bermanfaat bagi umat Islam. Dari Mesjidlah seharunya kaum Muslimin merancang masa depannya cemerlang, meliputi kegiatan keagamaan, ekonomi, politik, Pendidikan, sosial dan seluruh sendi kehidupan Umat. Hal ini sebagaimana yang dilakukan Rasulullah Saw dengan para sahabatnya (Khairuni \& Widyanto, 2018).

Namun faktanya masjid yang ada di Indonesia khususnya di Kabupaten Bandung Barat, Komplek Taman Bunga Cilame, berdasarkan hasil pengamatan penulis pengurus DKM belum maksimal dalam mengelola Mesjid. Mesjid hanya baru sebatas sebagai tempat Ibadah Mahdah dan beberapa kegiatan Sosial lainnya. Dan hal tersebut menurut pandangan penulis belum maksimal, yang paling terlihat belum 


\section{Jurnal Ilmiah Ekonomi Islam, 7(02), 2021, 664}

optimalisasinya peran masjid adalah dalam mengelola dana ZIS (Zakat Infaq dan Shodaqoh).

Mesjid mempunyai potensi yang sangat besar, jika masjid dikelola dengan baik. Adapun Sumber daya yang menjadi potensi masjid meliputi sumber daya insani, sumber daya yang bersifat fisik (tangible), sumber daya yang bersifat non-fisik (intangible) (Suryanto \& Saepulloh, 2016).

Potensi luar biasa dari zakat terlihat dari berita yang dikutip dari laman berita online detik news, yang menyampaikan berita bahwa Pemerintah Provinsi Jawa Barat menyebut jumlah penerimaan zakat fitrah pada Lebaran 2019 meningkat. Peningkatan mencapai 35 persen dibanding lebaran tahun lalu. Hal ini sebagaimana yang disampaikan Sekda Jabar Iwa Karniwa kepada wartawan di Gedung Pakuan, Kota Bandung, Rabu (5/6/2019) "Kenaikannya itu 35 persen dibanding tahun lalu,". (Ramadhan, 2019)

Namun, peran masjid dalam mengelola potensipotensi tersebut dewasa ini belum benar-benar terlihat peran dan fungsinya. Padahal kita sudah mempunyai contoh yang nyata dari seorang Utusan Allah yaitu Rasulullah Saw, yang memberikan contoh bagaimana masjid dijadikan sentra semua kegiatan Umat Islam tidak hanya yang terkait dengan urusan Ibadah tetapi urusan muamalah pun dilakukan di Mesjid.

Bahkan, Ketika pertama kali hijrah ke Madinah Rasulullah Saw Pada awal perkembangan da'wah Islam periode Madinah, tempat yang pertama kali dibangun adalah masjid, tepatnya adalah Masjid Quba. Pembangunannya didasari ketaqwaan kepada Allah SWT, yang kemudian penduduk sekitar mesjid ketika itu bergotong royong membantu Rasulullah Saw. Masjid tersebut didirikan oleh masyarakat dan untuk kepentingan masyarakat dalam rangka pengamalan ajaran Islam (Aziz Muslim, 2005).

Yang kemudian, turunlah ayat berikut:

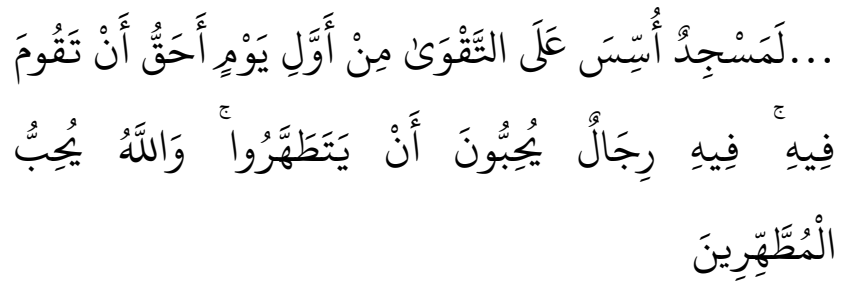

"Sesungguhnya masjid yang didirikan atas dasar taqwa (masjid Quba), sejak hari pertama adalah lebih patut kamu shalat di dalamnya. Di dalamnya ada orang-orang yang ingin mensucikan diri. Dan Allah menyukai orang-orang yang suci" (Q.S. al-Taubah: 108) (Departemen Agama RI, 2010)
Setelah pembangunan masjid Quba, Rasul SAW melanjutkan perjalanan ke Madinah, di sanapun yang pertama beliau lakukan ialah membangun masjid raya yang kemudian disebut masjid Nabawi.

Adapun Fungsi masjid pada masa Rasulullah SAW, antara lain: (Aziz Muslim, 2005)

1) tempat untuk melaksanakan ibadah mahdhah seperti: shalat wajib, shalat sunnah, i'tikaf, dan shalat-shalat sunnah yang bersifat insidental seperti shalat Ied, shalat gerhana dan sebagainya;

2) Sebagai pusat pendidikan dan pengajaran Islam. Rasulullah Saw sering menerima wahyu di masjid, yang kemudian beliau ajarkan kepada para sahabat dalam berbagai hal seperti hukum, kemasyarakatan, perundang-undangan dan berbagai ajaran lainnya.

3) Pusat informasi Islam. Jadi, Rasulullah Saw, sering menyampaikan berbagai macam informasi di Mesjid.

4) Tempat menyelesaikan perselisihan dan pertikaian, menyelesaikan masalah hukum dan peradilan serta menjadi pusat penyelesaian berbagai problem yang terjadi pada masyarakat. Fungsi selanjutnya.

5) Pusat kegiatan ekonomi. Yang dimaksud kegiatan ekonomi, tidak berarti sebagai pusat perdagangan atau industri, tetapi sebagai pusat untuk melahirkan ide-ide dan sistem ekonomi yang islami.

Jadi dengan penelitian ini, peneliti berharap bahwa kelak masjid Al Istiqomah Taman Bunga menjadi pusat kegiatan Umat islam tidak hanya saja yang berkaitan dengan ibadah saja. Sehingga, keberadaan masjid bisa memberikan manfaat yang lebih kepada masyarakat sekitar masjid.

\subsection{Gambaran Umum Mesjid Al Istiqomah} Taman Bunga Cilame.

Mesjid Al Istiqomah Komplek Taman Bunga terletak di Desa Cilame. Dan Desa Cilame merupakan salah satu desa dari 11 (sebelas) desa yang berada dalam wilayah Kecamatan Ngamprah Kabupaten Bandung Barat. Secara geografis Desa Cilame terletak di "jantung" Kabupaten Bandung Barat dengan kontur permukaan tanah berupa dataran dan sebagian perbukitan dengan ketinggian $600-750 \mathrm{M}$ di atas permukaan laut yang membentang dengan kordinat antara 107o - 31` Lintang Selatan dan 6o - 50` Bujur Timur serta luas wilayah mencapai $480 \mathrm{Ha}$ atau sama dengan 0,0272 \% dari luas Kabupaten Bandung Barat. (Wikipedia, 2016) 


\section{Jurnal Ilmiah Ekonomi Islam, 7(02), 2021, 665}

Mesjid Al Istiqomah Komplek Taman Bunga pertama kali didirikan pada Tahun 2012 hasil dari swadaya masyarakat warga RT 07, 10, 11 dan 12. Serta dari infak dan shadaqoh agniya. Namun, pada Tahun 2018 karena ada jalur Kereta Api Cepat Bandung - Jakarta, masjid Al Istiqomah lama karena tepat berada di jalur lintasan harus dipindahkan ke lokasi yang lain. Maka, pada tahun 2018 dilakukan pembangunan Mesjid Al Istiqomah di lokasi Baru. Dana pembangunan masjid bersumber dari dana penggantian dari Pemerintah dan juga swadaya Masyarakat dan sumbangan para dermawan.

Berdasarkan hasil wawancara penulis dengan Ketua DKM Mesjid Al Istiqomah, didapatkan informasi bahwa Masjid Al Istiqomah merupakan masjid ketiga dari tiga masjid yang ada di komplek taman Bunga Cilame, dan berdasarkan kesepakatan warga Komplek Taman Bunga. Masjid al Istiqomah diperuntukan untuk warga yang tinggal di RT 07, 10, 11 dan 12. Sejak pendiriannya Mesjid al Istiqomah sudah dijadikan pusat kegiatan Ibadah Mahdah meliputi shalat berjamaah 5 waktu, shalat ied, shalat gerhana, shalat tarawih dan penerimaan serta pendistribusian hewan qurban. Disamping itu juga menerima dan mengelola dana Zakat, infaq dan Shodaqoh. (A. Kurniawan, 2020 Agustus 10)

\subsection{Model Pengelolaan Zakat, Infaq Dan Shadaqah (ZIS) Di Mesjid Al Istiqomah Komplek Taman Bunga Cilame.}

Indonesia sebagai negara yang sebagian besar penduduknya beragama Islam, hal ini menjadi potensi yang sangat besar untuk mengentaskan kemiskinan dan mensejahterakan masyarakat. Dan, ini bisa tercapai jika zakat dikelola dengan baik dan benar, sehingga pengalokasian zakat sesuai dengan ajaran Islam (Rahim \& Sahrullah, 2017). Dalam pengelolaan zakat tidak hanya untuk memenuhi kewajiban syariat Islam, tetapi. Hendaknya amilin melakukan pengelolaan dana Zakat yang baik sesuai ketentuan seperti perhitungan zakat, pemungutan zakat, penyaluran zakat, dan akuntansi zakat dan pengungkapannya (Rahim \& Sahrullah, 2017).

Mesjid Al Istiqomah sejak pendiriannya sudah menerima dan mendistribusikan Zakat, Infaq dan Shadaqoh. Tetapi, pendistribusiannya hanya kepada Mustahik saja sehingga dana tersebut kemanfaatannya hanya sesaat. Padahal jika dikelola dengan baik, dana tersebut bisa mempunyai kemanfaatan yang mungkin lebih banyak dan lama.
Karena dewasa ini pengelolaan zakat haruslah diupayakan dan dirumuskan sedemikian rupa, sehingga dapat dikelola secara baik. Hendaknya, Aamilin (Pengelola Zakat) sudah membuat rumusan pengelolaan zakat berbasis manajemen. Dalam hal ini pengelola Zakat harus sudah menganggap bahwa pengelolaan zakat ini harus dilakukan secara professional (Ahmad Atabik, 2015).

Menurut M. Hasan (2011), yang dimaksud dengan profesional di sini adalah bahwa dalam pengelolaan zakat seluruh aktifitasnya saling keterkaitan satu sama yang lainnya. Yaitu, sosialisasi terkait dengan, pengumpulan, pendistribusian atau pendayagunaan, terkait dengan pengawasan. Semua kegiatan itu harus dilakukan menjadi sebuah kegiatan secara utuh, tidak dilaksanakan secara parsial atu bergerak sendiri-sendiri.

Dan yang menjadai dasar, bahwa zakat harus dikelola dengan baik adalah firman Allah dalam alQur' an surat al-Taubah ayat 103, firman-Nya:

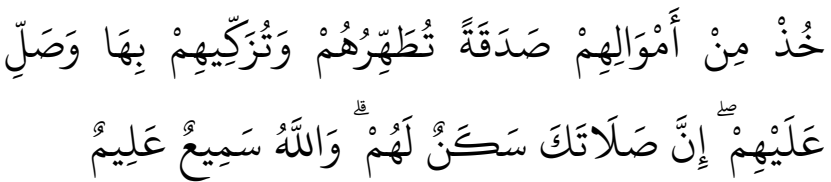

Artinya: Ambillah zakat dari sebagian harta mereka, dengan zakat itu kamu membersihkan dan mensucikan mereka dan mendoalah untuk mereka. Sesungguhnya doa kamu itu (menjadi) ketenteraman jiwa bagi mereka. Dan Allah Maha Mendengar lagi Maha Mengetahui (QS. AlTaubah: 103) (Departemen Agama RI, 2010).

Ayat tersebut di atas jika dipahami lebih dalam lagi, terlihat bahwa pada ayat tersebut ada kata yang menunjukan fiil amr (Kata perintah), yang mana menurut para ulama Ushul bahwa jika ada kata kerja yang menggunakan fiil amr, maka perbuatan yang diperintahkan tersebut merupakan wajib. Jadi, berdasarkan ayat tesebut mengambil, mengelola dan mendistribusikan Zakat adalah kewajiban. (M. Hasan, 2011)

Maka, supaya dana zakat terkelola dengan baik Para ulama mencoba untuk merumuskan tata cara mengelola zakat dengan baik. Dan para ulama mempunyai pandangan terkait dengan pengelolaan Zakat, diantaranya: (Ahmad Atabik, 2015)

Pertama, para ulama' sepakat bahwa yang berhak mengumpulkan zakat pada harta tetap dan mendistribusikannya adalah pemimpin yang ada pada suatu daerah kaum muslimin. Hal ini tidak boleh 


\section{Jurnal Ilmiah Ekonomi Islam, 7(02), 2021, 666}

ditangani secara perorangan, termasuk pendistribusiannya.

Kedua, para ulama' telah sepakat bahwa pengumpulan dan pendistribusian zakat pada harta bergerak, baik berupa uang maupun barang dagangan, dilakukan oleh pemimpin.

Dan dalam hal bagaimana cara pengelolaan dana zakat di Indonesia sudah ada peraturan perundangundangan yang mengatur hal tersebut yaitu undangundang No. 23 tahun 2011 tentang Pengelolaan Zakat, dan di dalamnya diatur bahwa: (1) Zakat dapat didayagunakan untuk usaha produktif dalam rangka penanganan fakir miskin dan peningkatan kualitas umat. (2). Pendayagunaan zakat untuk usaha produktif sebagaimana dimaksud pada ayat (1) dilakukan apabila kebutuhan dasar mustahik telah terpenuhi.

Undang-undang No. 23 tahun 2011 pasal (1) satu ayat (1) satu tersebut, memaknai bahwa pengelolaan zakat merupakan kegiatan perencanaan, pelaksanaan, dan pengorganisasian dalam pengumpulan, pendistribusian dan pendayagunaan zakat (Aziz, 2017).

Tata kelola dan manajemen yang baik dalam pengelolaan zakat, merupakan suatu keniscayaan dalam masyarakat modern. Kredibilitas pengelola zakat sangat tergantung pada pengelolaannya yang professional dan transparan. Sebab, selama ini para muzakki umumnya, lebih suka menyampaikan zakat secara langsung kepada mustahiq. Pembayaran zakat masih banyak dilakukan sendiri-sendiri mengikuti tradisi yang berlaku secara turun-temurun, tanpa pemahaman yang utuh (kaffah). Sehingga hal ini berakibat kepada pemanfaatan dan pendistribusiannya tidak merata, dan belum berdayaguna mengentaskan kemiskinan dan meningkatkan kesejahteraan umat (Ahmad Atabik, 2015).

Hal ini juga yang terjadi di Komplek Taman Bungga, khusunya yang terjadi pada DKM Mesjid Al Istiqomah sebagai pengelola dana ZIS, dan berdasarkan hasil wawancara peneliti dengan (Kurniawan, 2020) sebagai ketua DKM Mesjid Al Istiqomah. Beliau menginformasikan terkait proses pengelolaan keuangan serta beberapa kendala yang mereka hadapi, yaitu mereka belum mempunyai system yang terstruktur terkait dengan pengelolaan dana Zakat, Infaq dan Shadaqah (ZIS).

Padahal jika dikelola dengan baik dana ZIS Masjid al Istiqomah akan sangan bermanfaat untuk warga sekitar, karena seharusnya masjid bukan hanya menerima dan mengelola dana wakaf, zakat, infak, dan shadaqoh yang hanya digunakan untuk pembangunan masjid semata. Dengan adanya tata kelola yang baik terkait dengan pengelolaan ZIS, maka masjid memiliki program-program sosial seperti pengentasan kemiskinan, pemberian beasiswa, dan mengurangi jumlah pengangguran dengan program zakat produktifnya.

Sebagai bukti tidak adanya system pengelolaan dana ZIS yang baik di Mesjid Al Istiqomah, masih menurut (Kurniawan, 2020) pada tahun 2015 ada dua orang Jamaah Mesjid yang minjam dana ZIS untuk keperluan pribadinya. Jamaah pertama meminjam uang senilai Rp. 2.000.000 (Dua Juta Rupiah), dan Jamaah kedua meminjam Rp. 3.000.000 (Tiga Juta Rupiah), ketika keduanya meminjam uang tersebut mereka menjanjikan dalam satu bulan sudah mengembalikannya. Tetapi faktanya sampai sekarang tahun 2020 menurut beliau, uang yang dipinjam tersebut baru kembali Rp. 2.000.000, itupun pengembaliannya baru tahun 2017 padahal keduanya berjanji hanya minjam selama satu bulan saja.

Berangkat dari sana, menurut peneliti DKM harus mempunyai sistem menejemen yang baik menengai pengelolaan dana ZIS, sehingga dana ZIS tersebut bisa bermanfaat bagi umat dan bisa mensejahterakan masyarakat sekitar mesjid. Jangan sampai ada kejadian seperti yang sudah ketua DKM sampaikan di Atas. Bahkan, konon kata (Kurniawan, 2020) bahwa kedua jamaah yan meminjam uang tersebut berstatus sebagai pengurus DKM.

Menurut analisa penulis, ada beberapa model yang dapat digunakan dalam mempemberdayakan dana ZIS yang dapat dirumuskan berdasarkan potensi masjid yang ada. Yaitu dengan membuat model terintegrasi antara lembaga ZIS, keuangan mikro Islam dan pemberdayaan ekonomi masyarakat.

Di samping itu juga untuk memberikkan kepercayaan kepada masyarakat, DKM harus membuat sistem Manajemen yang baik dalam pengelolaan yang dana ZIS, dengan memperhatikan empat hal berikut sebagaimana yang disampaikan Ahmad Atabik (2015) berikut ini:

1) Pelayanan prima (service excellent) bagi muzakki dan mustahik dengan komitmen memberikan pelayanan yang tepat, cepat, benar dengan penanganan keluhan baik.

2) Dana Zakat Infak dan Shadaqah (ZIS) harus didayagunakan secara baik dan kreatif, inovatif tetapi sederhana dan memungkinkan dapat diakses oleh seluruh mustahik, sesuai dengan 


\section{Jurnal Ilmiah Ekonomi Islam, 7(02), 2021, 667}

kebutuhan, terukur serta berkelanjutan sehingga benar-benar mampu meningkatkan status mustahiq.

3) Administrasi dan laporan keuangan Zakat Infak dan Shadaqah yang akurat, tepat waktu, transparan dan manajemen, kredibel, dan dapat diakses oleh muzakki, mustahik dan stakeholder lainnya.

4) Produk dan program layanan ZIS yang kreatif dan inovatif yang membuat muzakki semakin meningkat kesadaran dan kemauannya untuk menunaikan ZIS.

Untuk mengatasi problematika dalam pemberdayaan dana Zakat, Infaq dan Shodaqah (ZIS) di Mesjid Al Istiqomah, ada beberapa model yang bisa dilakukan antara lain:

1) Model pengelolaan dana ZIS di Mesjid Al Istiqomah, kedepannya harus produktif dan kreatif agar dana ZIS tidak langsung habis, sehingga pendayagunaannya berpengaruh secara ekonomi dan pemberdayaan mustahik. Kegiatankegiatan yang bisa dilakukan seperti, pemberian modal tambahan kepada mustahik, Dalam pemberian modal ini DKM Bisa menggunkan akad-akad syariah seperti Aqad Mudharabah atau Musyarakah.

2) Melakukan kegiatan pendampingan dengan menggunakan pendekatan Participatory Action Research (PAR) kepada mustahik. Maksudnya, setelah memberikan modal usaha kepada jamaah atau warga sekitar yang membutuhkan, DKM harus melakukan pembinaan dengan melibatkan tenaga sukarelawan dalam membina masyarakat (mustahik), khususnya dalam hal pengembangan ekonomi masyarakat. Dengan adanya pendampingan dan pembinaan diharapkan mustahik bisa terus mengembangkan usahanya, sehingga nantinya modal tersebut dapat dikembalikan dan akan digulirkan lagi kepada mustahik yang lain.

Diharapkan dengan adanya model-model yang dibuat DKM dalam melakukan pengelolaan dana ZIS, hal tersebut bisa berdampak kepada perubahan kondisi seseorang dari yang semula sebagai mustahik (penerima) menjadi muzakki (pemberi), sehingga dengan bertambahnya jumlah muzakki tersebut akan mengurangi beban kemiskinan yang ada di masyarakat, khususnya di Komplek Taman Bunga Cilame, khususnya di wilayah sekitar Mesjid Al Istiqomah.

\section{KESIMPULAN}

Berdasarkan pemaparan yang sudah dijelaskan di atas, dapat diambil simpulan. Bahwa model pengelolaan dana ZIS di Mesjid Al Istiqomah, hanya dengan cara pendistribusian langsung kepada Mustahik saja sehingga dana tersebut kemanfaatannya hanya sesaat. Hal ini terjadi karena, masih ada ketidakjelasan sistem manajemen pengelolaan ZIS di Mesjid Al Istiqomah, sehingga dana ZIS yang terhimpun dirasa belum mempunyai nilai manfaat bagi masyarakat sekitar mesjid, dan kepercayaan masyarakat sekitar untuk menitipkan dana ZIS nya kurang.

Untuk mengatasi problema yang dihadapi tersebut DKM ada beberapa hal yang harus dilakukan Pengurus, untuk meningkatkan kepercayaan masyarakat, DKM harus membuat sistem manajemen yang baik dalam pengelolaan yang dana ZIS dengan memperhatikan empat Hal berikut: (1) Pelayanan prima kepada Muzakki dan Mustahiq, (2) Dana Zakat Infak dan Shadaqah (ZIS) didayagunakan secara baik dan kreatif, inovatif tetapi sederhana, (3) transfaransi dalam melakukan pelaporan dana ZIS, dan (4) kreatif dan inovatif dalam mengelola dana ZIS.

Dan model yang bisa digunakan dalam pengelolaan dana ZIS supaya Nilai manfaatnya lebih lama dan luas. DKM bisa membuat model berikut: (1) pemberian modal tambahan kepada mustahik dengan aqad Mudharabah atau musyarakah, (2) Melakukan mendampingan terhadap Mustahik yang sudah diberikan pinjaman modal dengan menggunakan pendekatan Participatory Action Research (PAR). Diharapkan dengan adanya pendampingan dan pembinaan diharapkan mustahik bisa terus mengembangkan usahanya, sehingga nantinya modal tersebut dapat dikembalikan dan akan digulirkan lagi kepada mustahik yang lain. Bahkan kedepannya status yang tadinya mustahik bisa menjadi muzakki, sehingga dengan bertambahnya muzakki dana ZIS yang terhimpun lebih banyak lagi, dan nilai manfaatnya akan lebih besar dan luas lagi.

\section{UCAPAN TERIMA KASIH}

Terimakasih yang sebesar-besarnya penulis sampaikan kepada Ketua beserta jajaran pengurus DKM Al Istiqomah Komplek taman Bunga Cilame, yang sudah berkenan meluangkan waktu dan memfasilitasi peneliti untuk melakukan kegiatan Pelatihan sekaligus Penelitian terkait Model Pengelolaan Zakat, Infaq Dan Shadaqah (Zis) Di 
Mesjid Al Istiqomah Komplek Taman Bunga Cilame, semoga kebaikan bapak beserta pengurus diberikan balasan yang setimpal oleh Allah Swt, Aamiin Yaa Rabb.

\section{REFERENSI}

Ahmad Atabik. (2015). Manajemen Pengelolaan Zakat yang Efektif di Era Kontemporer. ZISWAF : Jurnal Zakat Dan Wakaf, 2(1), 40-62.

Al-Qurthubi, I. (2006). Tafsir al-Jami'lil Ahkami al Quran. Muassasah Ar Risalah.

Aziz, M. (2017). Strategi Pengelolaan Zakat Secara

Produktif pada Lembaga Amil Zakat Dalam Tinjauan UU RI Nomor 23 Tahun 2011 Tentang Pengelolaan Zakat (Studi Kasus Di Nurul Hayat Kantor Cabang Tuban Periode 2015-2016). $A L$ HIKMAH: Jurnal Studi Keislaman, 7(14), 1-27.

Aziz Muslim. (2005). Manajemen Pengelolaan Masjid. Jurnal Aplikasi Llmu-Ilmu Agama, 5(2), 105-114.

Basid, A. (2009). Pemberdayaan Ekonomi Umat Berbasis Masjid (Pengalaman BMT Masjid Nurul Jannah Petrokimia Gresik). Al-Qānūn, Vol. 12, No. 1, Juni 2009, 12(1), 205-229.

Departemen Agama RI. (2010). Al Qur'an Tajwid dan Terjemahnya. CV. Dipenogoro.

Dwihapsari, Y. R. (2017). Analisis Pengaruh Pertumbuhan Ekonomi, Inflasi Dan Pengangguran Terhadap Kemiskinan Di Indonesia (2000-2015). العدد الحا (3), 43.

Gazalba, S. (1971). Masjid Pusat Ibadat dan Kebudayaan Islam. Pustaka Antara.

Hasan, A. (2006). Zakat dan Infak: Salah Satu Solusi Mengatasi Problema Sosial di Indonesia. Kencana Prenada Media Group.

Hasan, M. (2011). Manajemen Zakat: Model Pengelolaan Zakat yang Efektif. Penerbit Idea Press.
Khairuni, N., \& Widyanto, A. (2018). Mengatasi Krisis Spiritual Remaja di Banda Aceh Melalui Revitalisasi dan Optimalisasi Fungsi Masjid Sebagai Sarana Pendidikan Islam. DAYAH: Journal of Islamic Education, 1(1), 74-84.

Maleong, L. J. (2014). Metodologi Penelitian Kualitatif Edisi Revisi. PT Remaja Rosda Karya.

Masudi, M. F. (1993). Agama Keadilan: Risalah Zakat (Pajak) Dalam Islam. Pustaka Firdaus.

Moleung, L. J. (2005). Metode Penelitian Kualitatif. PT. Remaja Rosda Karya.

Munawir, A. W. (1984). Al Munawwir Kamus ArabIndonesia. Ponpes Krapyak.

Nasafi, A. (n.d.). Tafsir al Nasafi, Jilid 4. Darul Kutub Al-Arabi.

Nizar, M. (2016). Model Pemberdayaan Ekonomi Masyarakat Melalui Pengelolaan Zakat, Infaq Dan Shadaqah (Zis) Di Masjid Besar Syarif Hidayatullah Karangploso Malang. 8(1), 42-60.

Rahim, S., \& Sahrullah. (2017). Model Pengelolaan Zakat Perusahaan. Jurnal Akuntansi Multiparadigma, 200-215. https://doi.org/10.18202/jamal.2017.04.7049

Ramadhan, D. I. (2019). Meningkat 35 Persen, Penerimaan Zakat di Jabar Tembus Rp 403 M. Detik News, 1. https://news.detik.com/

Siskandar. (2020). Optimalisasi Masjid untuk Keaktifan Mahasiswa. Alim, Journal Islamic Education, 2(1), 85-100.

Suryanto, A., \& Saepulloh, A. (2016). Optimalisasi Fungsi dan Potensi Masjid; Model Pemberdayaan Ekonomi Masyarakat Berbasis Masjid di Kota Tasikmalaya. Iqtishoduna Vol.8 No.2, 8(2), 1-27.

Wikipedia. (2016). Cilame, Ngamprah, Bandung Barat. Https://Id.Wikipedia.Org/. https://id.wikipedia.org/ 